\title{
EFFECTS OF CHLORPROMAZINE ON SOME MOTOR REFLEXES*i
}

\author{
ROY D. Hudson and EDWARD F. DOMINO \\ Department of Pharmacology, The Universily of Michigan, Ann Arbor: Michigan
}

(Received 25 Febriary 1963)

\begin{abstract}
Summary-The effects of chlorpromazine (CPZ) on the patellar reflex and segmentally evoked spinal cord potentials were determined in various cal preparations. CPZ in doses of 1-8 $\mathrm{mg} / \mathrm{kg}$ given intravenously (as an accunulative dose) produced a significant depression of the patellar reflex and segmentally evoked potentials in animals with an intact central nervous system. Hypotension, potentiation of anesthesia, depression of nerve conduction in afferent and efferent nerves, an effect at the neuromuscular junction, or an effect directly on skeletal muscle or muscle spindle were ruled out as possible mechanisms of reflex depression.

Studies in high spinal and decerebrate animals (Sherrington, Pollock-Davis) and decerebellate suggested a supraspinal sight of $\mathrm{CPZ}$ action. CPZ was shown to cause a significant depression of facilitation and inhibition of the patellar reflex produced by electrical stimulation of the mesencephalic facilitatory and medullary inhibitory areas of the reticular formation. The linguomandibular reffex (LMR) was also elicited in several preparations. This reflex was significantly depressed in intact and high spinal animals while the patellar reflex was depressed only in the former. CPZ-induced depression of segmentally evoked potentials was demonstrated to be dependent upon the intensity of electrical stimulation. CPZ was much less effective in depressing potentials elicited by supramaximal than by submaximal stimuli ( 80 per cent of maxinum). The mean arterial blood pressure was depressed by CPZ in all preparations with an intact medullary vasomotor outflow.

The site of CPZ depression of these motor reflexes is probably on neurons in portions of the bulbar facilitatory (BF) reticular area as well as a lesser depression of neurons in portions of the bulbar inhibitory reticular areal. The possibility that CPZ may also act at a spinal level is discussed.
\end{abstract}

\section{INTRODUCTION}

MANY investigators have shown that CPZ reduces skeletal muscle tone in experimental animals (DASGuPTA and Werner, 1955; SHeATZ, 1955; and KreINDler et al., 1958) and in certain human hyperkinetic states (LehMANN and HANRAHAN, 1954; BASMAJIAN and Szatmari, $1955 \mathrm{a}, \mathrm{b}$; and COlE and Robertson, 1955). The neural mechanisms of CPZ reduction of skeletal muscle tone appear to be very complex. Henatsch and INGVar (1956) showed that small doses of CPZ abolish classical Sherringtonian decerebrate rigidity and gamma motor neuron discharge. On the other hand, much larger doses were required to depress the Pollock-Davis ischemic decerebrate rigidity and alpha motor neuron discharge. These investigators concluded that $\mathrm{CPZ}$ had a selective depressant effect on gamma as opposed to alpha motor systems. KRIVOY (1957) showed that CPZ. depressed both monosynaptic and polysynaptic spinal cord potentials in decerebrate and intact pentobarbital anesthetized cats. The electrical correlate of the patellar reflex (the monosynaptic potential) was depressed by CPZ more rapidly and profoundly than was the

*Supported by grant MY 2653 USPHS.

${ }^{+}$A preliminary paper was presented at the Federation Meetings in Atlantic City (Hudson and Domino 1961). 
polysynaptic discharge. SILvestriNI and MAFFI (1959) demonstrated that CPZ caused significant depression of the patellar and linguomandibular reflex in intact anesthetized cats. These investigators also showed that $\mathrm{CPZ}$ caused a greater depression of the poly synaptic linguomandibular reflex than the monosynaptic patellar reflex.

In marked contrast to the effects of CPZ in intact or decerebrate animals, CPZ even in very large doses produces no significant depressant effects on mechanically or electrically evoked reflexes in spinal animals (Preston, 1956; Henatsch and INGVAR, 1956; Bein, 1957; Kruglov. 1958; Silvestrint and MafFil, 1959; Krylov, 1960). The only exception is the report by DESAlva and OESTER (1960) that CPZ produced a significant depression of some monosynaptic and polysynaptic reflexes in acute high spinal preparations. BASMAJIAX and SZATMARI (1955 b) suggested that the skeletal muscle relaxant effects of CPZ may be due to a depressant effect on facilitatory areas of the brainstem. KREINDLER et al. (1958), KRUglov (1958) and VALdman (1962) offered evidence to support the hypothesis that CPZ acts on descending motor systems of the brainstem reticular formation.

The purpose of the present investigation was to elucidate further the site of action of CPZ on the patellar, linguomandibular, and segmental reflexes of the cat. The specific questions considered important to answer were: (1) Does CPZ exert an effect on any specific area of the spinal cord, reticular formation and cerebellum related to motor reflexes? (2) Is the hypotensive action of CPZ responsible for its motor depressant effects? (3) Is CPZ capable of depressing these motor reflexes independently of its ability to potentiati general anesthesia!?

\section{METHODS}

\section{Experiments with mechanically recorded reflexes}

Adult cats of both sexes ranging from $2 \cdot 0-4 \cdot 6 \mathrm{~kg}$ were used. Surgical operation was performed under open drop diethyl ether anesthesia. All cat preparations were suspended by clamps attached to the spinous processes. A bolt was inserted in the femur to provide an anchor for the leg in which the patellar reflex was elicited. Usually the head was fixed in a Horsley-Clarke stereotaxic apparatus. A mechanically operated hammer struck the patellar tendon once per second, eliciting the patellar reflex (PR) which was recorded on a kymograph. Body temperature was maintained thermostatically. Femoral arterial blood pressure was recorded in all preparations. Six variations of this basic preparation were used: (a) intact alpha-chloralose anesthetized cats with acutely implanted brainstem reticular electrodes, (b) intact anesthetized cats with mechanically stabilized blood pressure, (c) anesthetized high spinal (Cl) cats, (d) anesthetized cats with acute lesions of facilitatory or inhibitory brainstem reticular areas, (e) Sherrington (gamma) and. (f) Pollock-Davis (alpha) decerebrate cats.

Bipolar concentric electrodes were acutely implanted in preparations for brainstem stimulation in the mesencephalic facilitatory (BF) and medullary inhibitory (BI) reticular formation. These electrodes were positioned with a Horsley-Clarke stereotaxic apparatus. The co-ordinates for bulbar facilitation (BF) and bulbar inhibition (BI) of the patellar reflex were similar to those of KIN(i et al. (1955). Specifically these were:

BF: Posterior 2 to $--2 \mathrm{~mm}$

$$
\begin{array}{ll}
\text { Lateral } 2 \text { to } 5 \mathrm{~mm} \\
\text { Vertical } 0 \text { to }-7 \mathrm{~mm}
\end{array}
$$

BI : Posterior 11 to $16 \mathrm{~mm}$

$$
\begin{aligned}
& \text { Lateral } 0.5 \text { to } 1.5 \mathrm{~mm} \\
& \text { Vertical } \quad-5 \text { to }-10 \mathrm{~mm}
\end{aligned}
$$


In acutely lesioned preparations either the BF or BI area was destroyed electrolytically and the remaining area stimulated bipolarly.

The BECK (1958) blood pressure stabilizer was used in a series of animals in which the blood pressure was maintained at control levels. The reservoir was filled with approximately $100 \mathrm{ml}$ of heparinized blood of a donor cat. Tubing connecting the stabilizer to the animal was filled with a 0.3 per cent solution of heparin in physiological saline solution. In addition the animals received $3 \mathrm{mg} / \mathrm{kg}$ of heparin intravenously.

In the animals with acute reticular electrodes and those with high spinal (C1) section, the linguomandibular reflex (LMR) was elicited once every $5 \mathrm{sec}$ by an electric shock (3-5 V) applied bipolarly to the tongue. A pulse width of $1 \mathrm{msec}$ and a frequency of $100 \mathrm{cps}$ was used. The stimulus duration was $5 \mathrm{sec}$. Spinal animals were artificially respired at a rate of 18 strokes $/ \mathrm{min}$ and a tidal volume of $60-75 \mathrm{ml}$. A period of 2-3 hr was allowed in all preparations for elimination of ether.

\section{Experiments with acute dorsal-ventral root preparations for recording monosynaptic and polysynaptic potentials}

A spinal laminectomy was performed at the lumbosacral level for intradural isolation of the ipsilateral dorsal and ventral roots of segment L7 or SI. Following completion of surgery, wound edges were infiltrated with $2 \%$ xylocaine containing $0.001 \%$ epinephrine. The animal was then immobilized with decamethonium or $d$-tubocurarine and placed on artificial respiration. Four variations of this basic preparation were used: These were animals having an intact central nervous system (a) with and (b) without blood pressure stabilization, (c) Sherrington decerebrate and (d) decerebellate Sherrington decerebrate animals. These preparations were suspended by clamps attached to spinous processes and the curvature of the ilium. The reflected skin in the lumbar region was sutured to form a pool for warm mineral oil. Stimulation parameters were selected, the mineral oil pool temperature was adjusted thermostatically between $36-38^{\circ} \mathrm{C}$, and reproducibility of the reflex was determined during a period of 1 to $3 \mathrm{hr}$ following surgical operation. This period was also used to allow recovery from ether anesthesia. The dorsal root was stimulated with square wave pulses of $0.6-1.5 \mathrm{~V}$, of a duration of $0.5 \mathrm{msec}$, at a frequency of $2 \mathrm{c} / \mathrm{s}$. A sweep speed of $2 \mathrm{msec} / \mathrm{cm}$ and a $5 \mathrm{msec}$ delay were used. The distal end of the ventral root was crushed to produce monophasic spike potentials. The electrical responses were amplified and photograpind from the cathode ray oscilloscope with a Grass camera.

\section{RESULTS}

\section{Effects of CPZ on mechanically recorded reflexes with and without blood pressure stabilization}

In thirteen intact chloralose anesthetized cats, doses of $\mathrm{CPZ}$, increasing from 1 to 8 $\mathrm{mg} / \mathrm{kg}$ and given intravenously, caused marked decreases in the patellar and linguomandibular reflexes, and in mean arterial blood pressure, within $1 \mathrm{~min}$ after injection (Fig. 1). All three parameters measured were reduced approximately 30 per cent from control levels after the administration of $1.0 \mathrm{mg} / \mathrm{kg}$ of CPZ. Larger doses of CPZ caused no further depressions of the patellar reflex or of mean arterial blood pressure; in fact these responses gradually increased with cumulative dose. In all instances, the depressions of the patellar and linguomandibular reflexes and of mean arterial blood pressure were statistically significant $(P<0 \cdot 001)$. There was a striking parallelism between the falls in mean arterial 
blood pressure and in the patellar reflex. A similar parallelism in the depressions of the linguomandibular reflex (LMR) and of mean arterial blood pressure was present until a cumulative dose of $4 \mathrm{mg} / \mathrm{kg}$ of CPZ. At $8.0 \mathrm{mg} / \mathrm{kg}$ the LMR decreased at a time when blood pressure increased.

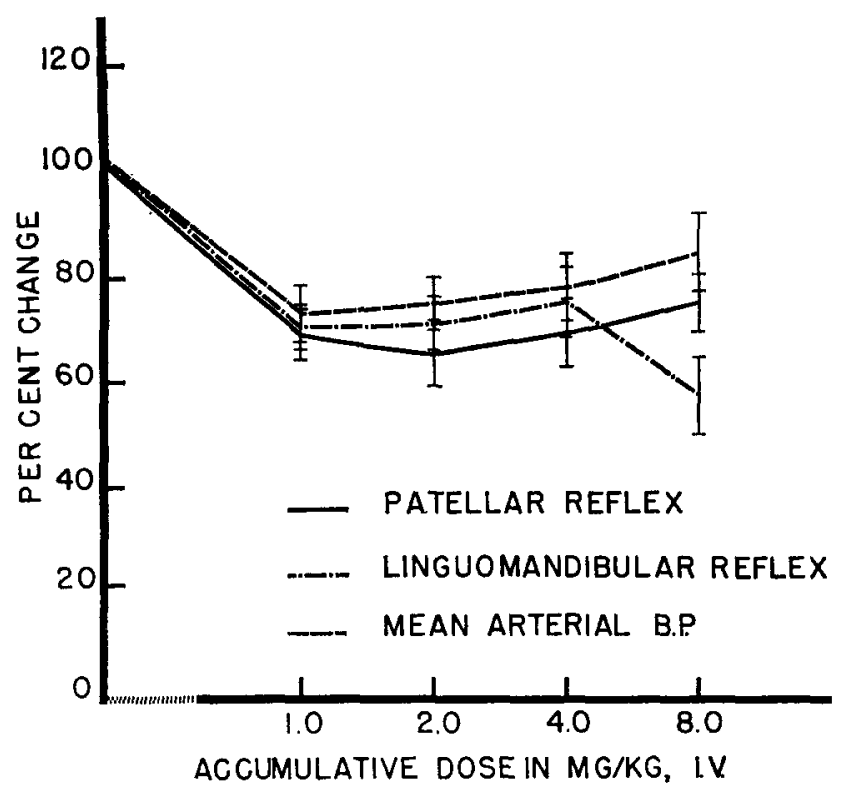

FIG. 1. Effects of CPZ on mean arterial blood pressure, patellar and linguomandibular reflexes in intact cats anesthetized with alpha-chloralose. The mean heights of the patellar and linguomandibular reflexes are expressed as the percent change from control. The mean arterial blood pressure also is expressed as percent change. Accumulative doses of CPZ are plotted logarithmically. The control period was $15 \mathrm{~min}$ and the interval between doses of CPZ was $10 \mathrm{~min}$. The data summarize the results obtained from thirteen animals. The short vertical bars represent \pm standard error.

The parallelism between the decrease in mean arterial blood pressure and depression of the patellar reflex suggested the possibility that the reflex reduction was secondary to the fall in blood pressure. Therefore, a blood pressure stabilizer was employed using the blood of a donor cat in the reservoir. Figure 2 illustrates a typical experiment using a cat with an intact central nervous system anesthetized with chloralose and stabilizing the arterial blood pressure at the animal's own blood pressure $(122 \mathrm{~mm} \mathrm{Hg})$. The height of patellar reflex during the control period is shown in panel $\mathrm{A}$. Within one minute after the administration of $1.0 \mathrm{mg} / \mathrm{kg}$ of $\mathrm{CPZ}$, there was a dramatic decrease in the size of the patellar reflex as illustrated in panel B. Even though the patellar reflex was decreased, the mean arterial blood pressure continued to be stabilized at $122 \mathrm{~mm} \mathrm{Hg}$. Doses of 2 and $4 \mathrm{mg} / \mathrm{kg}$ of CPZ caused a little more reduction in the height of the patellar reflex even though the blood pressure was maintained at the control level. Figure 3 illustrates a graph which summarizes the data obtained in six preparations with mean arterial blood pressure stabilization. It can be seen that although the mean arterial blood pressure did not vary from the control 
level of 100 per cent $(B P \pm S$.E. was $115 \pm 5 \mathrm{~mm} \mathrm{Hg}$ ), the mean height of the patellar reflex was significantly decreased with cumulative doses of $\mathrm{CPZ}$ from 1 to $8 \mathrm{mg} / \mathrm{kg}$ given intravenously. In contrast to the slight tendency for the patellar reflex to increase with larger doses of CPZ in intact animals, no such trend was observed in animals whose blood pressure was stabilized.

\section{A}

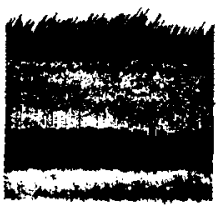

BP (STABILITED) ANMAL INTACT

CONTROL
$\mathbf{B}$

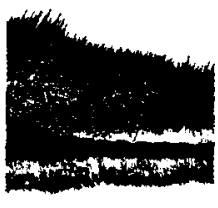

122

$1.0 \mathrm{MG} / \mathrm{KG}$

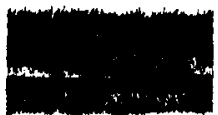

122

2.OMGKG

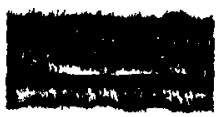

122

40 MG/KG

Fig. 2. Effects of CPZ on the patellar reflex in an intact alpha-chloralose anesthetized cat with blood pressure stabilized at control levels. The patellar reflex was elicited by mechanically tapping the patellar tendon every second. The blood pressure was stabilized at the animal's control pressure of $122 \mathrm{~mm} \mathrm{Hg}$. Time marks are at $10 \mathrm{sec}$ intervals.

Panel A. Control record.

Panel B. $1.0 \mathrm{mg} / \mathrm{kg}$ of CPZ given intravenously.

Panel C. $2.0 \mathrm{mg} / \mathrm{kg}$ of CPZ given intravenously as an accumulative dose $10 \mathrm{~min}$. later.

Panel D. $4.0 \mathrm{mg} / \mathrm{kg}$ of CPZ given intravenously as an accumulative dose another $10 \mathrm{~min}$ later.

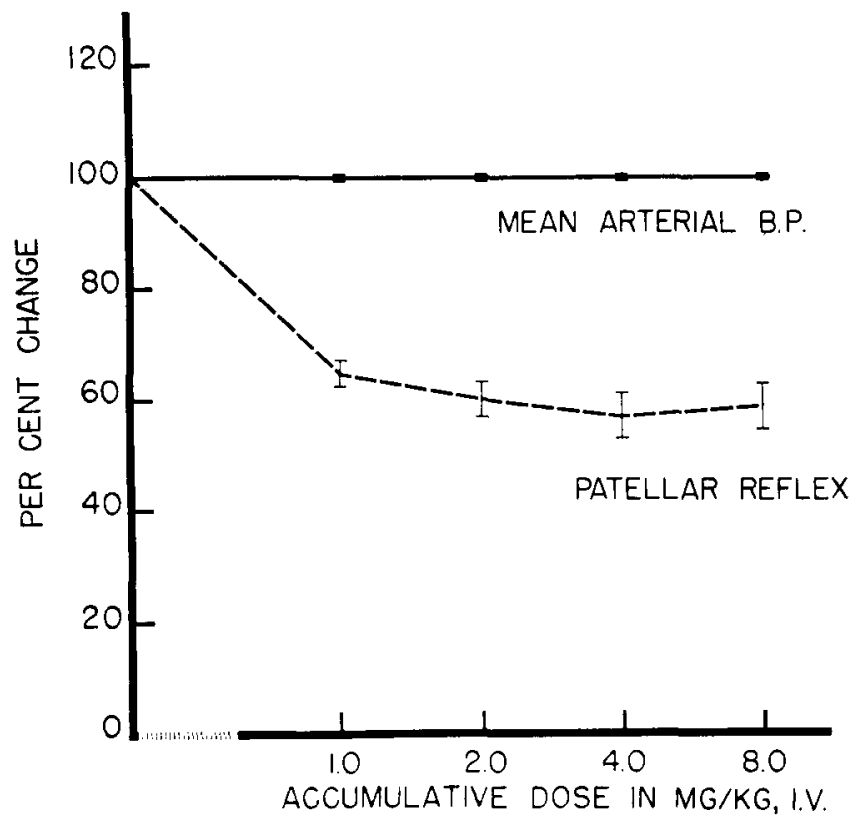

Fig. 3. Effects of CPZ on the mean patellar reflex in intact alpha-chloralose anesthetized cats with blood pressure stablized at control levels.

The data from six animals are expressed in the same manner as in Fig. 1. 


\section{Effects of $C P Z$ in high spinal chloralose anesthetized cats}

It might be argued that $\mathrm{CPZ}$ reduced the patellar reflex by a peripheral action. Therefore. acute high spinal cats were prepared for recording the patellar reflex. CPZ was administered in accumulative doses of $1-8 \mathrm{mg} / \mathrm{kg}$ within $2-4 \mathrm{hr}$ after high spinal (Cl) transection. Interestingly, in six such animals, CPZ produced no significant depressant effects on the patellar reflex or the mean arterial blood pressure. In fact, the patellar reflex gradually increased as did mean arterial blood pressure (Fig. 4). On the other hand, in these chloralose anesthetized high spinal cats, the linguomandibular reflex was significantly reduced by increasing doses of CPZ.

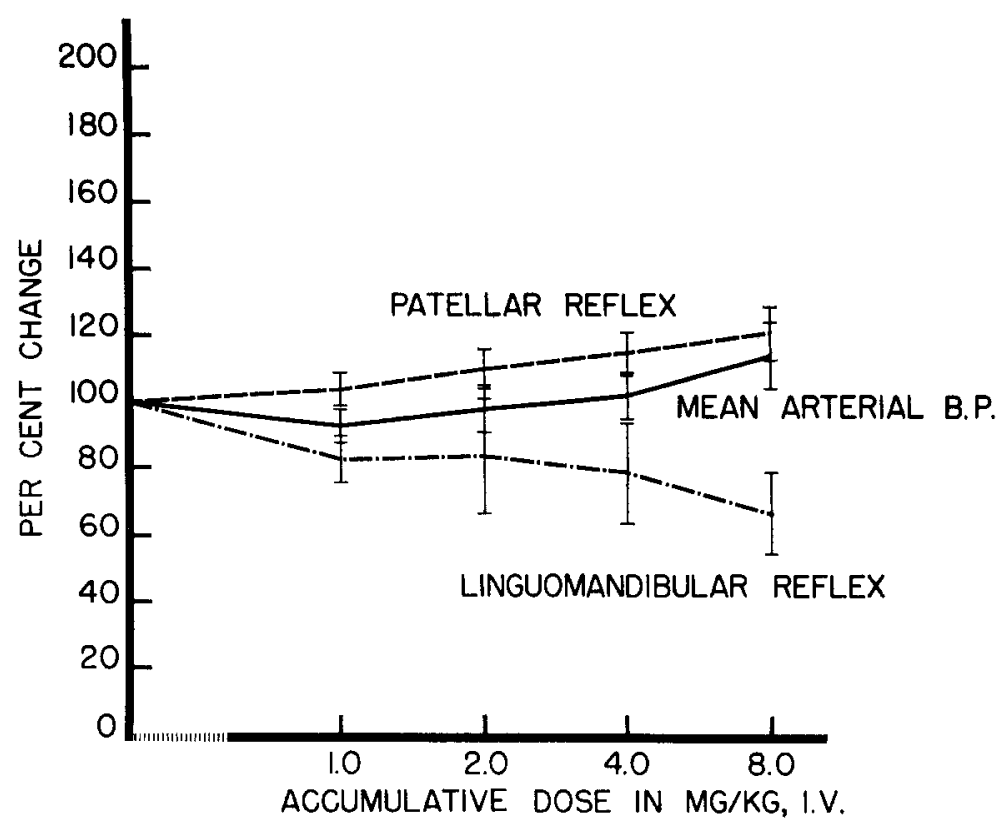

FIG. 4. Effects of $\mathrm{CPZ}$ on mean arterial blood pressure, patellar and linguomandibular reflexes in alpha-chloralose anesthetized high spinal cats. The experiment was begun 2 to $4 \mathrm{hr}$ after spinal cord transection. The data from six animals are expressed in the same manner as in

Fig. 1.

\section{Observations on patellar reflex recovery following high spinal section}

The failure of $\mathrm{CPZ}$ to depress the patellar reflex in acute high spinal preparations may have been caused by spinal shock induced by the acute transection. It seemed pertinent therefore to see if the patellar reflex was relatively normal within a few hours after spinal transection. Six cats under chloralose anesthesia were prepared for recording the patellar reflex before and after $\mathrm{Cl}$ transection. Figure 5 illustrates the pooled data on the course of recovery of the patellar reflex and mean arterial blood pressure in six animals during the first $6 \mathrm{hr}$ after $\mathrm{Cl}$ transection. Without exception, the patellar reflex was present immediately after spinal transection. The depression of the patellar reflex gradually subsided. Using the student " $t$ " test for paired comparison, the reflex was shown to be significantly depressed for 5 and 10 min after transection $(\mathrm{P}<05)$. Within $20 \mathrm{~min}$ after transection and subsequently the patellar reflex resumed at level similar to control $(\mathrm{P}>\cdot 2)$. 
The mean arterial blood pressure, in contrast, remained significantly depressed throughout the $6 \mathrm{hr}$ period $(\mathrm{P}<\cdot 02)$. Marked variability in responses of the patellar reflex were observed following spinal cord transection in each of the animals studied.

This same group of six animals were studied $24 \mathrm{hr}$ after spinal transection. They were given an additional $60 \mathrm{mg} / \mathrm{kg}$ of chloralose to reinduce anesthesia. Subsequently, CPZ was given intravenously in doses of $1-8 \mathrm{mg} / \mathrm{kg}$. Again, as in the acute high spinal transected animals studied within a few hours after surgery, CPZ had no significant effect in depressing the patellar reflex.

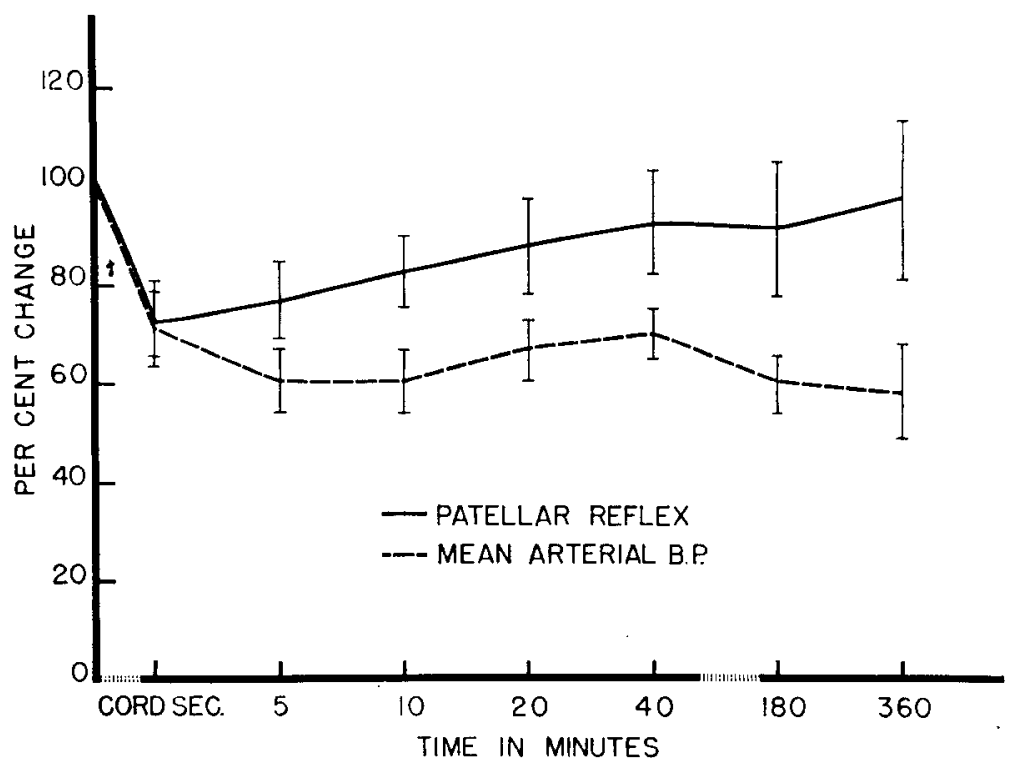

FIG. 5. Spontaneous change in the mean patellar reflex and arterial blood pressure after high spinal section (C1) in alpha-chloralose anesthetized cats.

Time in minutes after transection is plotted logarithmically. The mean height of the patellar reflex is expressed as the percent change from control. The mean patellar reflex and arterial blood pressure was determined for 15 min prior to transection and expressed as 100 per cent. The means of each variable were computed for six animals and are plotted at the time interval shown. The short vertical bars represent \pm the standard error.

\section{Effects of CPZ in decerebrate animals}

Seven cats were decerebrated under ether anesthesia by the classical method of SHERRINGTON (1898). This decerebration produces rigidity of the skeletal muscles which is mediated via the gamma motor system (Stella, $1944 \mathrm{a}$, b; GRANIT, 1955). The patellar reflex was difficult to elicit in these preparations because of the rigidity of the hind legs. After $1 \mathrm{mg} / \mathrm{kg}$ of CPZ was given intravenously, the rigidity was completely abolished and the amplitude of the patellar reflex increased parallel to the decrease in skeletal muscle tone. Marked variability was observed in the CPZ-induced enhancement of the patellar reflex. In spite of a marked increase in patellar reflex in some preparations, the paired comparison student " $t$ " test showed that results were not significant $(P>0 \cdot 9)$. The blood pressure, however, was significantly $(\mathrm{P}<0.02)$ depressed by $\mathrm{CPZ}$. 
Five cats were decerebrated using the ischemic method of PoLlock and Davis (1930, 1931). This type of decerebrate rigidity is mediated via the alpha motor system (STELLA, $1944 \mathrm{a}, \mathrm{b})$. Following ischemic decerebration and recovery from ether anesthesia a few of these animals exhibited the well-known erratic motor movements described by POLLOCK and Davis (1930, 1931), Granit (1955), and Borison et al. (1960). Although CPZ in doses of $1 \mathrm{mg} / \mathrm{kg}$ given intravenously abolished the spontaneous motor movements, the rigidity was not significantly depressed. The ischemic rigidity was extremely resistant to $\mathrm{CPZ}$ and was not abolished even by doses as high as $16 \mathrm{mg} / \mathrm{kg}$, although there was a slight reduction in tone. As in the case of the Sherrington decerebrate animals, there was an increase in the amplitude of the patellar reflex following CPZ $(1 \mathrm{mg} / \mathrm{kg}$, i.v. $)$. Considerable variability was also observed between animals in this regard. A statistical analysis using the paired comparison student " $t$ " test showed this increase was not significant $(P>0.5)$.

\section{Effects of CPZ on brainstem modification of the patellar reflex}

Thirteen cats anesthetized with chloralose were prepared for recording the patellar reflex and its modification by electrical stimulation of the mesencephalic facilitory (BF) and medullary inhibitory (BI) areas in the reticular formation. For purposes of clarity. the change in the mean height of the patellar reflex produced by electrical stimulation of $\mathrm{BF}$ and $\mathrm{BI}$ areas in the reticular formation will be referred to as reflex increment and decrement respectively. Decreased effectiveness of electrical stimulation to produce an increment or decrement will be designated as a depression. The reflex excursion not modified by reticular stimulation will be referred to as the basal patellar reflex. Stimulation of $\mathrm{BF}$ areas usually produced a reflex increment and an increase in mean arterial blood pressure. Stimulation of BI areas usually produced reflex decrement and a decrease in mean arterial blood pressure. Reverse effects from both areas were also observed indicating these sites are quite heterogenous. Accumulative doses of CPZ from 1 to $8 \mathrm{mg} / \mathrm{kg}$ given intravenously produced significant depressions of reflex increment and decrement (Fig. 6). Reflex increment showed a greater depression than reflex decrement. After administration of $1 \mathrm{mg} / \mathrm{kg}$ of $\mathrm{CPZ}$, reflex increment was depressed 33 per cent; after an accumulative dose of $8 \mathrm{mg} / \mathrm{kg}$ of $\mathrm{CPZ}$, it was depressed to 70 per cent of control. On the other hand, reflex decrement was decreased 30 per cent by $1 \mathrm{mg} / \mathrm{kg}$ of CPZ and remained essentially at this level with doses of CPZ up to $8 \mathrm{mg} / \mathrm{kg}$. No depression of reflex increment or decrement was observed in seven control preparations in response to equal volumes of physiological saline solution (Fig. 6).

\section{Effects of CPZ on monosynaptic and polysynaptic spinal cord potentials}

The effects of CPZ were studied on electrically evoked monosynaptic and polysynaptic segmental potentials in cats recovering from diethyl ether anesthesia and given either decamethonium or D-tubocurarine. As is illustrated in Fig. 7, submaximal ( 80 per cent of maximum) electrical stimulation of the dorsal root produced a characteristic spike ertifact followed by a large monosynaptic and polysynaptic discharge which was recorded from $L_{7}$ or $\mathrm{S}_{1}$ ventral root. The cat's blood pressure at this time was $120 \mathrm{~mm} \mathrm{Hg}$. Within a few minutes after the administration of $1.0 \mathrm{mg} / \mathrm{kg}$ of $\mathrm{CPZ}$, monosynaptic and polysynaptic discharges were depressed and the mean arterial blood pressure fell to $110 \mathrm{~mm} \mathrm{Hg}$. It can be noted in panel B, Fig. 7, that the monosynaptic potential was more depressed than the polysynaptic potentials. After an additional accumulative dose of $8 \mathrm{mg} / \mathrm{kg}$ of CPZ, the mean arterial blood pressure fell to $80 \mathrm{~mm} \mathrm{Hg}$. After such large doses of $\mathrm{CPZ}$, monosynaptic 


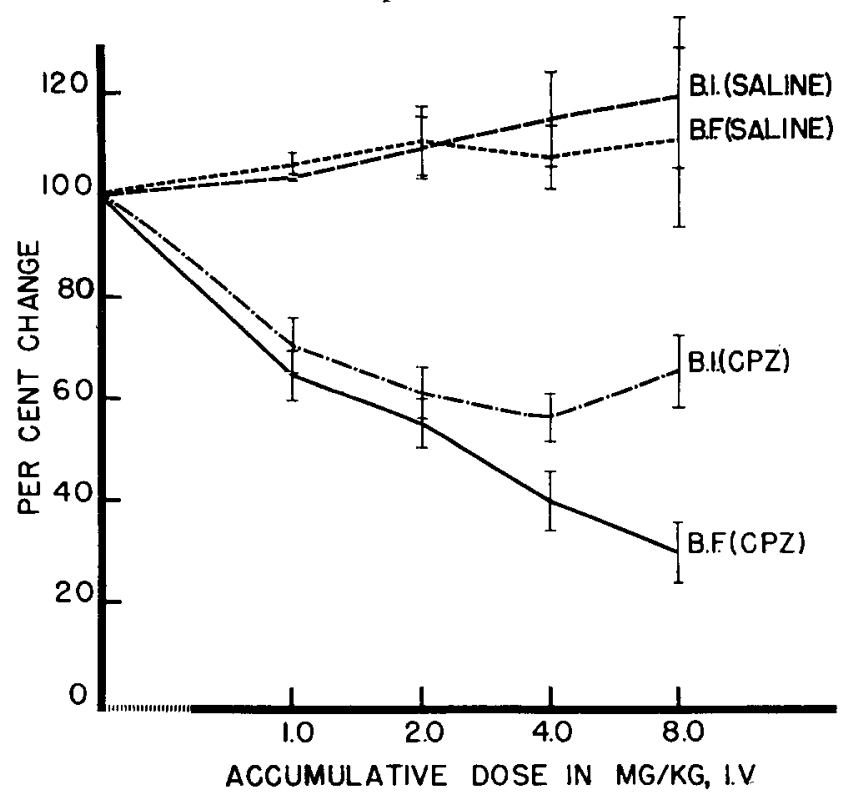

FIG. 6. Effects of $\mathrm{CPZ}$ and saline solution on reflex increment and decrement in alpha-chloralose anesthetized cats.

B.F. represents the mean per cent reflex increment during a 5 second period of electrical stimulation of a reticular facilitatory area. Reflex increment following doses of CPZ are expressed as percent change from the control increment.

B.I. represents the mean percent reflex decrement during a 5 second period of electrical stimulation of a reticular inhibitory area. Reflex decrement following doses of $\mathrm{CPZ}$ are expressed as percent change from the control decrement.

The data are expressed in the same manner as in Fig. 1.
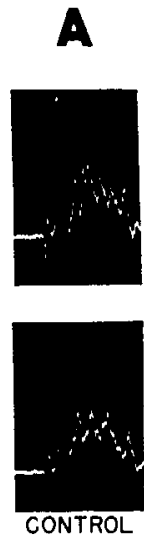

B.P. 120
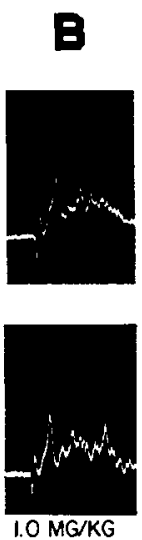

110
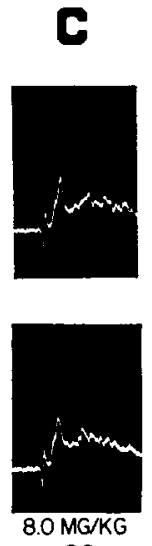

80
D
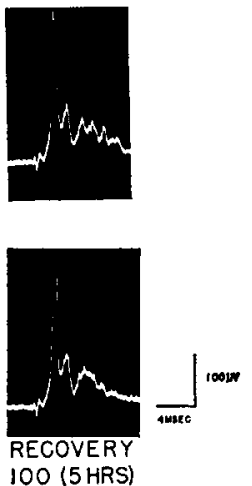

FrG. 7. Effects of $\mathrm{CPZ}$ on monosynaptic and polysynaptic action potentials of the segmental reflex of a cat immobilized with decamethonium.

Upper and lower potentials in panels A-D give some index of variability of responses. Submaximal ( 80 per cent max) stimulation of the dorsal root was used. The voltage and time base calibrations are indicated. Note the initial stimulus artifact followed by the mono- and polysynaptic discharge. The mean arterial blood pressure is shown below each panel in mm Hg. Panel A. Control.

Panel B. Potentials after $1.0 \mathrm{mg} / \mathrm{kg}$ of $\mathrm{CPZ}$ given intravenously.

Panel C. Potentials after $8.0 \mathrm{mg} / \mathrm{kg}$ of CPZ given intravenously.

Panel D. Partial recovery $5 \mathrm{hr}$ after $8 \mathrm{mg} / \mathrm{kg}$ of $\mathrm{CPZ}$ given intravenously. 
and polysynaptic discharges were only slightly more depressed than after $1 \mathrm{mg} / \mathrm{kg}$ (compare panel $\mathrm{C}$ to B, Fig. 7). Five hours after the last dose of CPZ, the monosynaptic and polysynaptic discharge recovered as is illustrated in panel D, Fig. 7. In order to demonstrate that these trends were statistically significant, eight cats immobilized by decamethonium and locally anesthetized were given 1 and $2 \mathrm{mg} / \mathrm{kg}$ of CPZ. A similar design was used in another eight cats locally anesthetized and immobilized by D-tubocurarine. The data summarized in Table 1 shows that CPZ caused a statistically significant decrease in the amplitude of both the monosynapatic and polysynaptic potentials in cats immobilized by decamethonium. The same doses of $\mathrm{CPZ}$ given to cats immobilized by D-tubocurarine produced a very significant depression of the monosynaptic potentials $(\mathrm{P}<0.001)$. Polysynaptic potentials were depressed but not to a highly significant level $(\mathrm{P}<0.07)$. The spinal cords of both types of immobilized preparations were transected at $\mathrm{Cl}$ after the cumulative dose of $2 \mathrm{mg} / \mathrm{kg}$ of $\mathrm{CPZ}$. This procedure resulted in a return toward control levels of the monosynaptic and polysynaptic potentials in both series of preparations.

TABLE 1. CPZ EFFeCtS ON MONO- AND POLYSYNAPTIC SEgMENTAL POTENTIALS AND MEAN ARTERIAL BLOOD PRESSURE $\pm \mathrm{SE}$.

\begin{tabular}{|c|c|c|c|c|c|}
\hline \multirow{2}{*}{$\begin{array}{l}\text { Accumulative } \\
\text { dose } \\
\text { (mg/kg, i.v.) }\end{array}$} & \multirow[b]{2}{*}{$\begin{array}{l}\text { Parameters } \\
\text { monitored }\end{array}$} & \multicolumn{2}{|c|}{$\begin{array}{l}\text { Preparations immobilized } \\
\text { by decamethonium }\end{array}$} & \multicolumn{2}{|c|}{$\begin{array}{l}\text { Preparations immobilized } \\
\text { by D-tubocurarine }\end{array}$} \\
\hline & & $\begin{array}{l}\text { Mean percent } \\
\text { of control } \pm \mathrm{SE}\end{array}$ & $P$ value & $\begin{array}{l}\text { Mean percent } \\
\text { of control } \pm \mathrm{SE}\end{array}$ & $P$ value \\
\hline Control & $\begin{array}{l}\text { Monosynaptic } \\
\text { Polysynaptic } \\
\text { MABP }\end{array}$ & $\begin{array}{l}100 \\
100 \\
100\end{array}$ & & $\begin{array}{l}100 \\
100 \\
100\end{array}$ & \\
\hline $1 \cdot 0$ & $\begin{array}{l}\text { Monosynaptic } \\
\text { Polysynaptic } \\
\text { MABP }\end{array}$ & $\begin{array}{l}51 \cdot 1 \pm 13 \cdot 3 \\
54 \cdot 1 \pm 13 \cdot 9 \\
83 \cdot 9 \pm 3 \cdot 0\end{array}$ & $\begin{array}{l}<0.02 \\
<0.05 \\
<0.01\end{array}$ & $\begin{array}{l}49 \cdot 0 \pm 9 \cdot 7 \\
57 \cdot 8 \pm 15 \cdot 3 \\
80 \cdot 3 \pm 3 \cdot 7\end{array}$ & $\begin{array}{l}>0.001 \\
<0.07 \\
<0.01\end{array}$ \\
\hline $2 \cdot 0$ & $\begin{array}{l}\text { Monosynaptic } \\
\text { Polysvnaptic } \\
\text { MABP }\end{array}$ & $\begin{array}{l}38 \cdot 2 \pm 18 \cdot 4 \\
45 \cdot 3 \pm 10 \cdot 5 \\
70 \cdot 4 \pm 4 \cdot 5\end{array}$ & $\begin{array}{l}>0.01 \\
>0.001 \\
<0.001\end{array}$ & $\begin{array}{l}34 \cdot 0 \pm 12 \cdot 0 \\
44 \cdot 3 \pm 20 \cdot 6 \\
71 \cdot 4 \pm 3 \cdot 1\end{array}$ & $\begin{array}{l}<0.001 \\
<0.07 \\
<0.001\end{array}$ \\
\hline Cord section & $\begin{array}{l}\text { Monosynaptic } \\
\text { Polysynaptic } \\
\text { MABP }\end{array}$ & $\begin{array}{l}63 \cdot 6 \pm 16 \cdot 6 \\
94 \cdot 6 \pm 23 \cdot 9 \\
51 \cdot 8 \pm 2 \cdot 5\end{array}$ & $\begin{array}{l}<0.1 \\
>0.8 \\
<0.001\end{array}$ & $\begin{array}{l}44 \cdot 3 \pm 16 \cdot 7 \\
67 \cdot 7 \pm 20 \cdot 7 \\
57 \cdot 9 \pm 3 \cdot 1\end{array}$ & $\begin{array}{l}>0.01 \\
<0.211 \\
<0.001\end{array}$ \\
\hline $1 \cdot 0$ & $\begin{array}{l}\text { Monosynaptic } \\
\text { Polysynaptic } \\
\text { MABP }\end{array}$ & $\begin{array}{r}64 \cdot 5 \pm 20 \cdot 5 \\
108 \cdot 1 \pm 29 \cdot 3 \\
57 \cdot 0 \pm 3 \cdot 2\end{array}$ & $\begin{array}{l}<0.2 \\
<0.8 \\
<0.001\end{array}$ & $\begin{array}{l}45 \cdot 4 \pm 27 \cdot 7 \\
68 \cdot 6 \pm 26 \cdot 6 \\
58 \cdot 9 \pm 3 \cdot 6\end{array}$ & $\begin{array}{l}>0 \cdot 1 \\
>0 \cdot 3 \\
<0 \cdot 001\end{array}$ \\
\hline $2 \cdot 0$ & $\begin{array}{l}\text { Monosynaptic } \\
\text { Polysynaptic } \\
\text { MABP }\end{array}$ & $\begin{array}{r}76 \cdot 6 \pm 22 \cdot 2 \\
126 \cdot 4 \pm 40 \cdot 8 \\
57 \cdot 7 \pm 4 \cdot 2\end{array}$ & $\begin{array}{l}>0.4 \\
<0.9 \\
<0.001\end{array}$ & $\begin{array}{l}56 \cdot 0 \div 23 \cdot 3 \\
76 \cdot 2 \div 26 \cdot 4 \\
62 \cdot 1 \pm 3 \cdot 5\end{array}$ & $\begin{array}{l}>0 \cdot 1 \\
>1 \cdot 4 \\
>0 \cdot 001\end{array}$ \\
\hline
\end{tabular}

The peak height of monosynaptic and polysynaptic potentials are expressed as per cent of control. A paired comparison student " $t$ " test was used for each dose comparing the observed response to control. MABP represents the mean arterial blood pressure. 
Fig. 8 illustrates the potentials of an animal immobilized with decamethonium before and after cord transection. Additional doses of 1 and $2 \mathrm{mg} / \mathrm{kg}$ of CPZ after spinal transection produced no depression of monosynaptic or polysynaptic potentials (Table 1). The mean arterial blood pressure was significantly depressed $(P<0.01)$ in animals with an intact cerebrospinal axis. After spinal cord transection CPZ produced no further depression of mean arterial blood pressure. The intravenous injection of equal volumes of physiologic saline solution produced no significant effects on the mean arterial blood pressure in segmentally evoked potentials in six cats locally anesthetized and immobilized by decamethonium.

The arterial blood pressure was stabilized in five additional dorsal-ventral root preparations immobilized with decamethonium. CPZ in doses of $1-8 \mathrm{mg} / \mathrm{kg}$ given intravenously caused depressions of both the monosynaptic and polysynaptic potentials similar to those observed in animals without blood pressure stabilization.
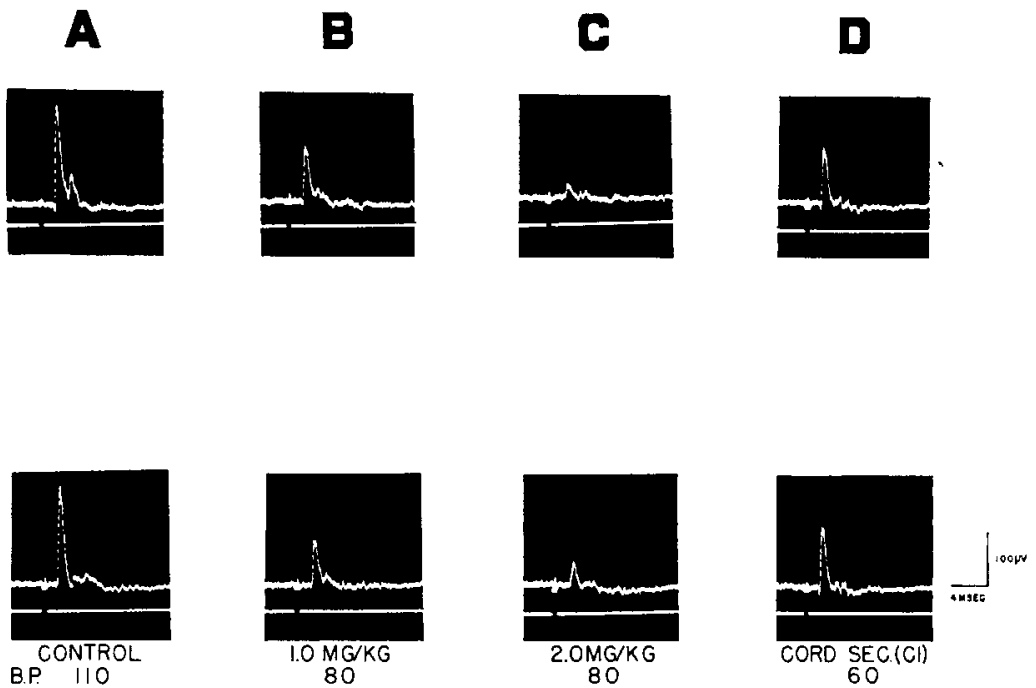

FIG. 8. Effects of $\mathrm{CPZ}$ on monosynaptic and polysynaptic action potentials of the segmental reflex of a cat immobilized with decamethonium.

Upper and lower potentials in panels A-D give some index of variability of responses. Submaximal stimulation of the dorsal root was used. The upper trace of a dual beam oscilloscope was used to visualize the evoked response and the lower trace for the stimulus artifact. Symbols and calibrations are similar to those used in Fig. 7.

Panel A. Control.

Panel B. Potentials after $1.0 \mathrm{mg} / \mathrm{kg}$ of CPZ given intravenously.

Panel C. Potentials after $2.0 \mathrm{mg} / \mathrm{kg}$ of $\mathrm{CPZ}$ given intravenously.

Panel D. Potentials within a few minutes after spinal cord section at $\mathrm{Cl}$. Note partial return of the responses.

\section{Effects of CPZ on monosynaptic and polysynaptic spinal cord potentials elicited by supramaximal electrical stimulation}

It was observed that increasing the voltage of stimulation in a preparation with CPZdepressed monosynaptic and polysynaptic responses antagonised the depression. Therefore, the effects of CPZ were systematically studied in preparations using supramaximal electrical 
stimulation or the dorsal roots. A supramaximal stimulus was arbitrarily set at $1 \cdot 75$ times the voltage required to produce the largest obtainable monosynaptic spike potential. The effects of CPZ in doses from 1 to $8 \mathrm{mg} / \mathrm{kg}$ were tested in eight such dorsal-ventral root preparations. It was noted that the monosynaptic spike was characteristically much more resistant to large doses of CPZ. In spite of supramaximal stimulation of the dorsal roots the polysynaptic potentials were significantly depressed at all dose levels $(P<0.05)$. However, it should be noted that at this voltage, the polysynaptic responses are only approximately 50 per cent maximal (LLoyd, 1943). The summarized data for all eight animals is illustrated in the bar graph in Fig. 9. It can be seen that the reduction in the monosynaptic response represents approximately a 10 per cent decrease. Because of the variability between preparations this maximal depressant effect was not significantly different from the control $(\mathrm{P}>0 \cdot 2)$. On the other hand, the polysynaptic potentials were significantly depressed as was mean arterial blood pressure $(\mathrm{P}<0 \cdot 01)$.

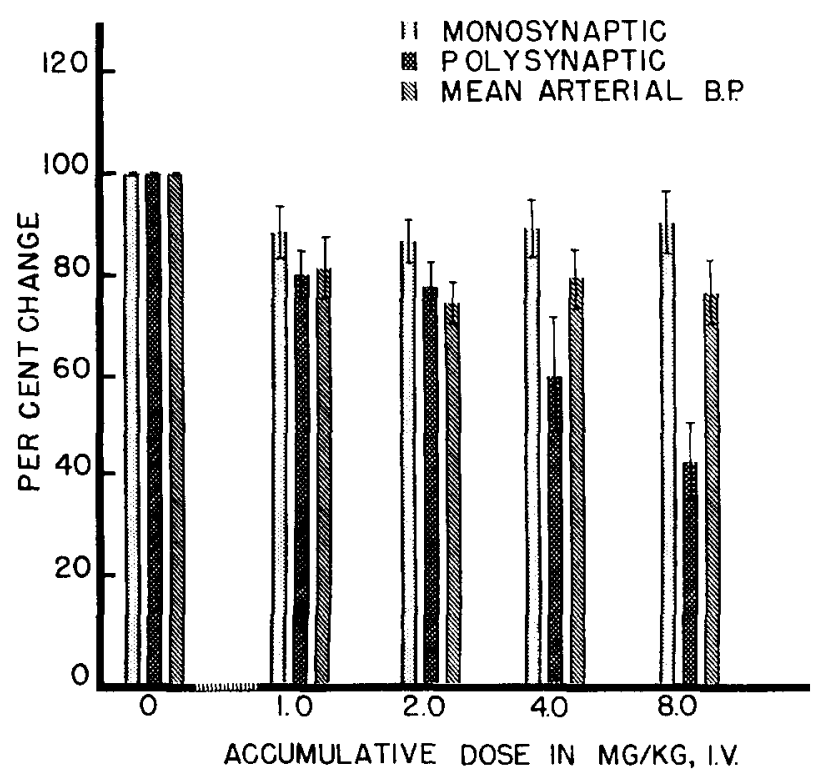

FIG. 9. Effects of CPZ on the mean arterial blood pressure and amplitude of the monosynaptic and polysynaptic action potentials of the segmental reflex elicited by supramaximal stimulation in cats immobilized with D-tubocurarine.

The heights of the various bars represent the mean monosynaptic and polysynaptic action potentials expressed as per cent $\mu \mathrm{V}$ amplitudes and the mean arterial blood pressure as per cent change in $\mathrm{mm} \mathrm{Hg}$. The control data was obtained in a $15 \mathrm{~min}$ period prior to CPZ. The interval between doses of CPZ is $10 \mathrm{~min}$. The data summarize the results obtained in six animals. The short vertical lines represent \pm the standard error. Note that although CPZ depressed polysynaptic discharge and mean arterial blood pressure it had much less of an effect on the monosynaptic potential.

\section{Effects of CPZ on monosynaptic and polysynaptic spinal cord potentials in} Sherrington decerebrate animals

Eight preparations with a dorsal-ventral root exposure plus a mid-collicular, prepontine transection were studied. Submaximal ( 80 per cent of maximum) stimulation of 
the dorsal roots was utilized. Both monosynaptic and polysynaptic potentials were observed to be significantly depressed $(P<0.001)$ by accumulative doses of 1 and $2 \mathrm{mg} / \mathrm{kg}$ of CPZ, as illustrated by the bar graph in Fig. 10. This depression was similar to that observed in preparations with an intact cerebrospinal axis. The first dose of CPZ also abolished the rigid condition of the animals in addition to reducing monosynaptic and polysynaptic discharge. Mean arterial blood pressure was also significantly reduced $(\mathrm{P}<0.001)$. Increasing the voltage of stimulation to a supramaximal level caused a significant increase in monosynaptic and polysynaptic action potentials without producing a similar effect on the mean arterial blood pressure.

Six mid-collicular pre-pontine transected animals prepared with a dorsal-ventral root exposure for stimulation and recording were also decerebellated. CPZ in doses of 1-4 $\mathrm{mg} / \mathrm{kg}$ caused a significant reduction in the amplitude of the monosynaptic and polysynaptic potentials of these decerebellated Sherrington decerebrate animals. Interestingly, the rigidity of the preparations was not abolished until the animals had been given approximately $2 \mathrm{mg} / \mathrm{kg}$ of CPZ. An increase in the amplitude of the potentials was observed in all animals in this series if opisthotonus was induced by raising or turning the head before as well as after administration of CPZ. As in previous preparations the mean arterial blood pressure was significantly depressed $(\mathrm{P}<0.001)$. A group comparison student " $\mathrm{t}$ " test revealed that the effects of $\mathrm{CPZ}$ on mean arterial blood pressure and monosynaptic and polysynaptic potentials in this series were not significantly different from the Sherrington decerebrate nor animals with intact cerebrospinal axis $(P>0.5)$.

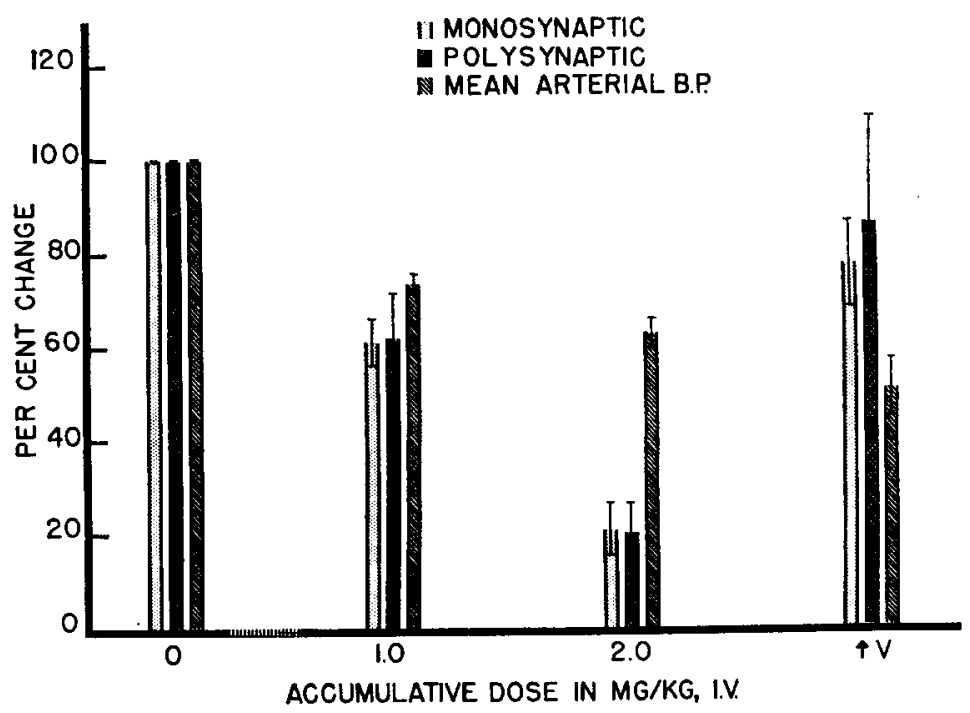

FIG. 10. Effects of $\mathrm{CPZ}$ on the mean amplitude of the monosynaptic and polysynaptic action potentials of the segmental reflex and arterial blood pressure in Sherrington (gamma motor driven) decerebrate cats.

The data are for six animals and are expressed in a manner similar to that of Fig. 8 . Following supramaximal stimulation of the dorsal root $(\uparrow V)$ the monosynaptic and polysynaptic potentials markedly increased toward control in spite of the fact that they previously were depressed by $2.0 \mathrm{mg} / \mathrm{kg}$ of $\mathrm{CPZ}$. 


\section{Effects of CPZ on the patellar reflex of animals with lesions of the reticular formation}

The BF area delineated in the Methods section was electrolytically destroyed in eight cats anesthetized with chloralose. Destruction of this area caused significant depressions of the patellar reflex and mean arterial blood pressure. Stimulation of the remaining BI area produced a characteristic reflex decrement. This was significantly depressed by $\mathrm{CPZ}$ $(P<0.01)$. The markedly reduced patellar reflex showed no further depression following $\mathrm{CPZ}$.

The BI area delineated in the Methods section was destroyed in seven cats anesthetized with chloralose. In contrast to the BF-lesioned cats, the patellar reflex was significantly enhanced. The mean arterial blood pressure showed some depression. Stimulation of the remaining $\mathrm{BF}$ area produced a characteristic reflex increment. This ieflex increment was progressively depressed by accumulative doses of CPZ. Surprisingly, the markedly enhanced patellar reflex was not depressed by CPZ. In fact there was a trend to a slightly further increase which was not significant. Using the group comparison student " $t$ " test there was no significant difference in the depressions of reflex increment in the intact and BIlesioned animals. On the other hand, $\mathrm{CPZ}$ was more effective in reducing reflex decrement in BF-lesioned than intact animals $(P<0 \cdot 001)$.

\section{DISCUSSION}

CPZ produces a significant reduction in the amplitude of the patellar reflex of cats anesthetized with alpha-chloralose. There are several possible mechanisms for this effect. These include: (1) hypotension (KISSEL and Domino, 1959), (2) potentiation of anesthesia (COURVOISIER et al., 1953; DoBKIN et al., 1954), (3) depression of afferent or efferent nerve conduction (CourvoIsIER et al., 1953; KOPERA and ARMITAGE, 1954), (4) depression of transmission across the neuromuscular junction (SU and LEE, 1960), (5) direct muscle fiber depression (KOPERA and ARMITAGE, 1954), (6) depression of the muscle spindle and (7) a direct effect on the central nervous system (DASGUPTA and WERNER, 1955; HENATSCH and INGVAR, 1956).

The arterial blood pressure was stabilized to rule out hypotension as the primary factor for CPZ-induced depression of the patellar reflex, monosynaptic and polysynaptic potentials. In spite of blood pressure stabilization, CPZ still produced its characteristic reflex depressant effects. Spinal cord as well as cerebral blood flow has been demonstrated to be passively controlled by the systemic blood pressure (Отомо et al., 1960). Stabilization of systemic blood pressure would therefore either have no effect on blood flow through the central nervous system or would increase it. An alteration in blood flow under conditions of systemic blood pressure stabilization probably is not a significant factor in CPZ-induced reflex depression. These experiments indicate further that CPZ exerted a reflex depressant effect independent of its hypotensive property. However, the elevation of the patellar reflex which occurred after administration of large doses of CPZ to the intact animal (Fig. 1) may be related to CPZ-induced hypotension since this did not occur in experiments with blood pressure stabilization.

Potentiation of anesthesia also was ruled out as the primary mechanism of CPZinduced reflex depression. $\mathrm{CPZ}$ always produced a significant depression of monosynaptic and polysynaptic segmental potentials in decerebrate and in intact, locally-anesthetized cats immobilized by neuromuscular blocking agents. CPZ also had no effect on the patellar reflex of chloralose anesthetized high spinal cats. 
The possibility that CPZ was depressing afferent or efferent nerve conduction, transmission across the neuromuscular junction, the muscle spindle or contractile elements of skeletal muscle also was ruled out. These possible actions were unlikely because of the lack of sensitivity of high spinal animals to CPZ evidenced when either the patellar reflex or segmental potentials were recorded. It appeared, therefore, that CPZ exerted its effects directly on the central nervous system. Theoretically, the site of action could be at the level of the spinal cord, bulbar reticular formation, cerebellum or other extrapyramidal or pyramidal motor systems. CPZ could either decrease facilitation or stimulate inhibition at any of these levels. The lack of depressant effects of $\mathrm{CPZ}$ in the acute high spinal animal would tend to rule out any significant direct spinal cord effects. One might argue that CPZ fails to produce depression of the patellar reflex in acute spinal animals because they are in spinal shock. The results of this study would indicate that the patellar reflex returns to control levels within 20 minutes following cord transection in the chloralose-anesthetized cat. Inasmuch as $\mathrm{CPZ}$ was given two as well as $24 \mathrm{hr}$ after transection, the failure of $\mathrm{CPZ}$ to depress the patellar reflex cannot be ascribed to an already depressed reflex. Unless the spinal cord transection cut off a crucial motor input to the spinal cord, it would appear that CPZ acts at a supraspinal site.

The Sherrington decerebrate preparation (gamma motor driven) was used to rule out the effects of CPZ on cerebral areas related to spinal motor reflexes (LINDSLEY et al., 1949; PEACOCK and Hodes, 1951; Hodes et al., 1951). CPZ produced its characteristic depressant effects on monosynaptic and polysynaptic spinal cord potentials in this preparation. Therefore, it can be concluded that CPZ exerts motor depressant effects below the mesencephalic transection. Similar conclusions have been made by DASGUPTA and WERNER (1955), Preston (1956), Henatsch and IngVar (1956) and Bein (1957) using a variety of mechanical and electrical recording techniques. CPZ caused an increase in the amplitude of the patellar reflex in the decerebrate preparation. This appeared to be a paradox since electrically evoked monosynaptic and polysynaptic potentials in the decerebrate preparation were depressed by CPZ. Nevertheless, both observations can be interpreted to be due to supraspinal depression. In the decerebrate animal both flexor and extensor tone is exaggerated (HENNEMAN and SCHERRER, 1949). CPZ may reduce both flexor and extensor tone, but the extensor tone is greater in the cat and apparently some remains when flexor tone is abolished. The depression of extensor tone produced a fall in the baseline, and the depression of flexor tone allowed an increased amplitude to the patellar reflex. The tone decrease is probably due to depression by $\mathrm{CPZ}$ of exaggerated supraspinal reticular output. Electrophysiologic potentials showed only depression following CPZ. Such an apparent lack of correlation of the myostatic reflex and the monosynaptic response has also been observed under different conditions by Granit (1955, p. 236).

The cerebellum is intricately involved with motor activity (LINDSLEY et al., 1949; GRANIT, 1955) and could be a possible site of the motor depressant effects of CPZ. Extirpation of the cerebellum in the Sherrington decerebrate animal produced a pillar-like rigidity which was depressed by CPZ. Electrical potentials in such preparations were also significantly depressed. Such a depression in the absence of the cerebellum indicated that this structure was not the primary site of action of CPZ. The rigidity of such preparations was abolished by a slightly larger dose of $\mathrm{CPZ}$ than that required to abolish Sherrington decerebrate rigidity (gamma motor driven). The Pollock-Davis (alpha motor driven) decerebrate rigidity was not abolished except at high dose levels of CPZ in confirmation of the observations of HENATSCH and INGVAR (1956). The rigidity produced in the decerebellated-decerebrate preparation appears to have both gamma and alpha motor 
driven components as suggested by its sensitivity to CPZ. It appears that removal of the posterior cerebellum in addition to the anterior lobe weakens the rigidity and resistance to CPZ. The posterior cerebellum apparently exerts a facilitatory effect on downstream motor reflexes (BROOKHART, 1960).

Among the structures in the pontobulbar areas of the brain that have important influences on the mediation of gamma motor systems are the bulbar facilitatory (GRANIT, 1955; Grant and Holmgren, 1955) and bulbar inhibitory (MAGOUN, 1944; SNIDER et al., 1949) reticular areas. Theoretically a BF area may be depressed or a BI area stimulated to produce depression of the patellar reflex. CPZ administered to intact cats in which the reticular formation was electrically stimulated bipolarly caused a significant depression of reflex increment and decrement. The depression of reflex increment was marked while reflex decrement was less affected. CPZ never enhanced reflex decrement. CPZ-induced depression of facilitation combined with a partially active inhibition may be the basis for the depression of the patellar reflex in the intact animal. On the basis of this investigation it appears that $\mathrm{CPZ}$ produces a differential depression of certain $\mathrm{BF}$ and $\mathrm{BI}$ reticular areas. KRUGLOV and SiNITSYN (1959) made similar observations using monopolar stimulation of the reticular formation and cerebellum. Under these circumstances much current spread would be expected. KILLAM (1962) suggested that such a study needed confirmation in bipolarly stimulated preparations. This is now accomplished. KRYLOV (1960) proposed that the depressant effect of CPZ on the patellar reflex of intact animals may in part be related to depression of sympathetic activity. KELLY and BACH (1959) demonstrated that the integrity of the lumbar sympathetic chain is necessary for maintenance of the basal height of the patellar reflex. The infusion of phenoxybenzamine $(10 \mathrm{mg}$ in $100 \mathrm{ml})$ caused a decrease of the patellar reflex. This is a very important observation since it is well known that skeletal muscles have sympathetic as well as sensory and motor innervation (KUNTZ, 1947). Although a peripheral effect may be contributory to patellar reflex depression, the electrophysiological evidence suggests in addition a direct central action of CPZ. A more difficult point to determine is whether spinal cord section interrupts a flow of impulses from reticular areas which may be blocked by CPZ at spinal cord levels. Direct stimulation of the spinal cord to mimic such descending facilitatory or inhibitory influences may be a means of testing this possibility, but looking at the change in the patellar reflex gives no indication whether this is alpha or gamma motor neuron mediated. Cross circulation experiments in which $\mathrm{CPZ}$ is given to the recipient head appear essential to establish conclusively the supraspinal action of CPZ.

Inasmuch as CPZ is a peripheral alpha adrenergic blocking agent (HuIDOBRo, 1954; LEAR et al., 1956), it is pertinent to ask if such an action centrally can account for depression of the patellar reflex. The fact that alpha adrenergic blocking agents like phenoxybenzamine (DBZ) depress the patellar reflex of intact cats (KELLY and BACH, 1959) but not spinal cats (KISSEL and Domino, 1959) suggests an analogy with the demonstrated effects of CPZ. Whatever may be the role of central alpha adrenergic blockade in altering the basal patellar reflex, facilitation of this reflex by brainstem stimulation (reflex increment) is not dependent on catecholamines in the central nervous system. MCLENNAN (1961) showed that reserpine $(0.5 \mathrm{mg} / \mathrm{kg} /$ day for 3 days $)$ changed reflex decrement to refiex increment. Of course this does not necessarily mean that this is due to depletion of central catecholamines, inasmuch as reserpine is known to affect the serotonin, acetylcholine, and gamma-aminobutyric acid levels as well. KELLY and BACH (1959) demonstrated that $\mathrm{DBZ}$ abolished the patellar reflex but produced no depression of reflex increment. CRANMER 
et al. (1959) showed small doses of $\mathrm{DBZ}(0.25 \mathrm{mg})$ changed reflex decrement to increment. Because reflex increment is known to be resistant to the effects of alpha adrenergic blockers and reserpine, it would appear that the alpha adrenergic blocking property of CPZ probably does not account for the depression of reflex increment. This is strengthened by the recent observations of one of us that $\mathrm{CPZ}$ is effective in reducing refiex increment in reserpinized cats in whom the basal patellar reflex already was markedly depressed.

Inhibition of the patellar reflex by stimulation of reticular inhibitory areas (reflex decrement) has been demonstrated to be blocked by dichloroisoproterenol (DCI) $7 \mathrm{mg} / \mathrm{kg}$ given intravenously or topically applied to the spinal cord (MCLENNAN, 1961) and DBZ $0.25 \mathrm{mg}$ administered via the intravenous or intramedullary route (CRANMER et al., 1959). MCLENNAN (1961), however, was unable to show any effects of CPZ and DBZ $(20 \mathrm{mg} / \mathrm{kg}$, i.v.) on reflex decrement, but he did show that CPZ and DBZ were effective in blocking the depression of the patellar reflex caused by epinephrine in the anesthetized cat. The apparant contradiction between CRANMER et al. (1959) and MCLENNAN (1961) as to the effects of $\mathrm{DBZ}$ on reflex decrement may be due to the differences in doses used. Since DCI and DBZ have been shown to block reflex decrement, it would appear that there may be at least two inhibitory mechanisms within the central nervous system for lower motor reflex inhibition. Terzuolo (1954) was able to elicit reflex decrement via reticular stimulation after large doses of strychnine which would be expected to block Renshaw inhibitory neurons (ECCLES et al., 1954; ECCLES, 1957). This suggests that reticular inhibition may operate through a mechanism different from that known to exist at the segmental level (PATton, 1960). The fact that DCI is effective in blocking reflex decrement when applied topically to the cord, and that DBZ is only effective when given intravenously or into the medulla, may indicate a segmental receptor for reflex decrement of the "beta" type and a supraspinal receptor of the "alpha" type. CPZ may therefore produce depression of reflex decrement via an alpha mechanism. Since this compound is capable of depressing the patellar reflex, reflex increment and decrement, it would appear that a more complex mechanism than alpha adrenergic blockade is involved. Further investigation is necessary to analyze the mechanism by which these reflexes are mediated and altered by pharmacologic agents. The recent observations of VALDMAN (1962) that CPZ may depress facilitation and inhibition of the patellar reflex due to stimulation of some reticular neurons and not others certainly suggests that several descending neuronal systems are involved, some of which are sensitive to CPZ and others which are not. This also makes any data obtained from large lesions of the reticular formation very difficult to interpret. The observations of HENATSCH and INGVAR (1956) that the gamma motor system is sensitive to CPZ while the alpha motor system is resistant certainly offers a clue as to the course of future experiments. It is vital that alpha and gamma motor neuron influences be determined whenever any spinal cord or reticular area is stimulated to modify motor reflex mechanisms.

\footnotetext{
Résumé-Les effets de la Chlorpromazine (CPZ) sur réflexe patellaire et sur les potentiels évoqués par stimulation segmentaire de la moelle sont déterminés chez le chat, en différentes préparations.

L'administration intra-veineuse, en dose cumulative, de 1-8 $\mathrm{mg} / \mathrm{kg}$ entraîne une dépression significative du réflexe patellaire et des potentiels évoqués segmentaires chez les animaux à système nerveux cetral intact.

L'hypotension, la potentialisation de l'anethésie, la dépression de la conduction nerveuse dans les nerfs afférents et efférents, une action à la jonction neuro-musculaire ou un effet
} 
direct sur le muscle squelettique ou le fuseau musculaire ont été rejetés comme mécanismes possibles de la dépression des réflexes.

Des études effectuées sur des animaux spinaux supérieurs $\left(C_{1}\right)$ et décérébrés (Sherrington, Pollock-Davis et Sherrington décérébellés) suggèrent un point d'impact supra-spinal de la CPZ. La Chlorpromazine s'est révélée être à l'origine de la dépression significative de la facilitation et de l'inhibition du réflexe patellaire engendré par stimulation électrique des aires faciliatrices mésencéphaliques et inhibitrices médullaires de la Formation Réticulaire. Le réflexe linguomandibulaire a également été étudié dans plusieurs préparations. Ce réflexe est significativement diminué chez les animaux intacts et spinaux supérieurs alors que la dépression du réflexe patellaire n'est présente que chez les premiers. La dépression, induite par la CPZ, des potentiels évoqués segmentairement s'est montrée dépendante de l'intensité de la stimulation électrique. Les potentials induits par des stimuli supramaximaux sont nettement moins déprimés par la CPZ que ceux évoqués par des stimuli submaximaux ( $80 \%$ due maximum).

La tension artérielle moyenne est diminuée par la CPZ dans toutes les préparations avec intégrité du système vaso-moteur médullaire.

L'action de la CPZ sur ces réflexes moteurs s'exerce probablement sur les neurones de certaines parties de l'aire réticulaire bulbaire facilitatrice et dans une moindre mesure sur les neurones de l'aire bulbaire inhibitrice. Le possible point d'impact de la CPZ au niveau spinal est discuté.

Zusammenfassung - Die Effekte des Chlorpromazins (CPZ) auf den Patellarreflex und auf die segmental ausgeloesten spinalen Nervenpotentiale wurden in verschiedenen Katzenpraeparaten bestimmt, CPZ, das in Dosen von $1-8 \mathrm{mg} / \mathrm{kg}$ (als akkumulative dosis) i.v. einspritzen wurde, verursachte eine eindeutige Daempfung des Patellarreflexes und der segmental ausgeloesten Potentiale bei Tieren mit intaktem Zentralnervensystem. Blutdrucksenkung, Vertiefung der Narkose, Unterdrueckung der afferenten and efferenten Nervenleitung, Einfluss auf die Nerv-Muskelverbindung sowie ein unmittelbarer Effekt auf Skeletmuskeln oder Muskelspindeln wurden als moegliche Mechanismen der Reflexdaempfung ausgeschlossen.

Studien an Tieren mit hoher spinallãhmung oder Decerebration (Sherrington, PollockDavis) lassen auf einen supraspinalen Ort der CPZ Wirkung schliessen. Es wurde gezeigt, das CPZ eine eindeutige Unterdrueckung der Foerderung und Hemmung der Patellarreflexe, die durch elektrische Reizung der mesencephalen Foerderungs- und medullaeren Hemmungsbereich ausgeloest wurden, bewirkte. Der Linguo-Mandibular Reflex (LMR) wurde ebenfalls in verschiedenen Praeparaten ausgeloest. Diester Reflex wurde bei intaken Tiren und solchen mit hoher Spinalanaesthesie eindeutig unterdrueckt, waehrend der Patellarrefiex nur bei der ersten Gruppe gehemmt wurde. Es wurde gezeigt, dass eine CPZ induzierte Daempfung der segmental ausgeloesten Potentiale von der Intensitaet der elektrischen Reizung abhaengig ist. CPZ war bedeutend weniger wirkungsvoll in der Daempfung uebermaximaler Reize als in der Daempfung untermaximaler Reize (80 Prozent des Maximums). Der arterielle Durchschnittsblutdruck wurde durch CPZ in allen mit einem intakten Vasomotorensystem augestatteten Praeparaten unterdrueckt.

Es kann hieraus gefolgert werden, dass der Ort der CPZ-Daempfung der Motorreflexe wahrscheinlich in Neuronen gelegen ist, die sowohl in Teilen der bulbaer-foerdernden (BF) Retikulargebiete als auch in Teilen der bulbaerhemmenden Retikulargebiete lokalisiert sind. Die Moeglichkeit, das CPZ auch in spinalen Bereich wirken koennte, wird eroertert.

Author's address-DR. E. F. Domino, Department of Pharmacology, University of Michigan, Ann Arbor, Michigan.

\section{REFERENCES}

Basmajtan, J. V. and Szatmari, A. (1955a). Effects of Largactil (chlorpromazine) on human spasticity and electromyogram. A.M.A. Arch. Neurol. Psychiat. 73: 227-231, 225-231.

Basmajian, J. V. and Szatmari, A. (1955b). Chlorpromazine and human spasticity. An electromyographic study. Neurol. 5: 856-860.

BeCK, L. (1958). An automatic blood pressure stabilizer and volume recorder. Univ, of Mich. Med. Bull. 24: $118-120$.

Bern, H. J. (1957). Effects of reserpine on the functional strata of the nervous system. In Garatrini, S. and Ghetri, V., ed. Psychotropic Drugs. Elsevier, Amsterdam, 325-331. 
Borison, H. L., Clark, W. G. and Rosenstein, R. (1960). Functional decerebration in the cat-comparative evaluation of cerebral ischemia and ultrasonic midbrain transection. Neurol. 10: 931-941.

Brand, E. D., Harris, T. D., Borison, H. L. and Goodman, L. S. (1954). The anti-emetic activity of 10-( $\gamma$-dimethylaminopropyl)-2-chlorophenothiazine (chlorpromazine) in dog and cat. J. Pharmacol. 110: $86-92$.

Brookmart, J. M. (1960). The Cerebellum. p. 1245 in: Fields, J., ed. Handbook of Physiology, Vol. 2 (Sec. 1). American Physiological Society, Washington, D.C.

Cole, A. C. E. and Robertson, D. H. H. (1955). Chlorpromazine in the management of tetanus. Lancet 269: $1063-1064$.

Courvoisier, S., Fournel, J., Ducrot, R., Kolsky, M. and Koetschet, P. (1953). Propriétés pharmacodynamiques du chlorhydrate du chloro-3 (diméthylamino-3' propyl)-10 phénothiazine (4.560R.P.) Etude expérimentale d'un nouveau corps utilisé dans l'anesthésie potentialisée et dans l'hibernation artificielle. (Pharmacodynamic properties of RP 4.560, experimental study of a new compound used in potentiated anesthesia and artificial hibernation). Arch. int. Pharmacodyn. 92: 305-361.

Cranmer, J. I., Brann, A. W. and Bach, L. M. N. (1959). An adrenergic basis for bulbar inhibition Amer. J. Physiol. 197: 835-838.

DAsGuPta, S. R. and Werner, G. (1955). Inhibitory actions of chlorpromazine on motor activity. Arch. int. Pharmacodyn. 100: 409-417.

DeSalva, S. J. and Oester, Y. T. (1960). The effect of central depressants on certain spinal reflexes in acute high cervical cat. Arch. int. Pharmacodyn. 124: 255-262.

Dobkin, A. B., Gilbert, R. G. B. and Lamoureux, L. (1954). Physiological effect of chlorpromazine. Anaesthesia 9: 157-174.

ECCLes, J. C. (1957). The Physiology Nerve Cells. Johns Hopkins, Baltimore.

ECCles, J. C., FAtT, P. and KoKetsu, K. (1954). Cholinergic and inhibitory synapses in a pathway from motor-axon collaterals to motoneurones. J. Physiol. 126: 524-562.

Granit, R. (1955). Receptors and sensory perception. Yale Univ. Press, New Haven, 191-220.

Granit, R. and Holmgren, B. (1955). Two pathways from brain stem to gamma ventral horn cells. Acta physiol. Scand. 35: 93-108.

HeNatsch, H. D. and IngVar, D. H. (1956). Chlorpromazin und spastizitat: Ein experimentelle elektrophysiologische Untersuchung. Arch.f. Psych. u. Zeit. Neurol. 195: 77-93.

Henneman, E. and Scherrer, J. (1949). The effect of a,b-dihydroxy- $\gamma$-(2-methylphenoxy) propane (myanesin, tolserol) on experimental spasticity in cats. J. Pharmacol. 97: 342-348.

Hodes, R., Peacock, S. M., Jr. and Heath, R. G. (1951). Influence of the forebrain on somato-motor activity-I Inhibition. J. Comp. Neurol. 94: $381-408$.

Hudson, R. D. and Domino, E. F. (1961). Evidence for a brainstem action of chlorpromazine on some motor reflexes. Fed. Proc. 20: 307.

Huidobro, F. (1954). Some pharmacological properties of chloro-3-(dimethylamine-3'propyl) 10-phenothiazine or 7.560 R.P. Arch. int. Pharmacodyn. 98: 308-319.

KeLLY, H. B., Jr. and BACH, L. M. N. (1959). Blocking interactions between brain-stem reflex facilitation and sympathetic reflex enhancement. Amer. J. Physiol. 196: 669-673.

Killam, E. K. (1962). Drug action on the brain-stem reticular formation. Pharm. Reviews 14: 175-223.

King, E. E., Minz, B. and UnNA, K. R. (1955). The effect of the brain stem reticular formation on the linguomandibular reflex. J. Comp. Neurol. 102: 565-596.

Kissel, J. W. and Domino, E. F. (1959). Effects of controlled progressive hypotension on some spinal reflexes in the cat. Amer. J. Physiol. 196: 59-64.

Kopera, J. and Armitage, A. K. (1954). Comparison of some pharmacological properties of chlorpromazine, promethazine and pethidine. Brit. J. Pharmacol. 9: 392-401.

Kreindler, A., Steriade, M., Zuckermann, E. and Chimion, D. (1958). The influence of chlorpromazine upon cerebello-cortical and cerebello-spinal circuits. Electroenceph. clin. Neurophysiol. 10: 515-520.

KrIvoY, W. A. (1957). Actions of chlorpromazine and of reserpine on spinal reflex activity in the cat. Proc. Soc. exp. Biol. 96: 18-20.

Kruglov, N. A. (1958). The influence of aminazine and mepazine on central transmission of excitation in certain motor reflexes. Pharmacol. and Toxicol. (Farmakologiya I Toksikologiya) 21: 34-38. 
Kruglov, N. A. and Sinitsyn, L. N. (1959). The effect of aminazine and mepazine on the cerebellar and bulbar inhibitory mechanisms. Pharmacol. Tox. 22: 97-101.

KryLov, O. A. (1960). The action of bromide. Fiziol. Lh. SSR. 46: 1258-1264.

Kuntz, A. (1947). Sympathetic nerves in relation to skeletal muscles-autonomic nervous system. 4th E Lea and Febiger, Philadelphia.

Lear, E., Chiron, A. E. and Pollin, I. N. (1956). Some interesting pharmacodynamic properties of chlorpromazine. J. Clin. exp. Psychopath. 17: 147-152.

Lehmann, H. E. and Hanrahan, G. E. (1954). Chlorpromazine-new inhibiting agent for psychomotor excitement and manic states. A.M.A. Arch. Neurol. and Psychiat. 71: 227-23

Lindsley, D. B., SChreiner, L. H. and MaGoun, H. W. (1949). An electromyographic study of spasticity. J. Neurophysiol. 12: 197-205.

LLoyd, D. P. C. (1943). Reflex action in relation to pattern and peripheral source of afferent stimulation. J. Neurophysiol. 6: 111-119.

Magoun, H. W. (1944). Bulbar inhibition and facilitation of motor activity. Science 100: 549-550.

MCLenNAN, H. (1961). The effect of some catecholamines upon a monosynaptic reflex pathway in the spinal cord. J. Physiol. 158: 411-425.

Otomo, E., Wolbarsht, M. L., Van Buskirk, C. and Davidson, M. (1960). A comparison of spinal cord, cortical and superficial circulation. J. Nerv. Ment. Dis. 131: 418-427.

Patton, H. D. (1960). Reflex regulation of movement and posture, in Ruch, T. C. and Fulton, J. F. eds. Medical Physiology and Biophysics., W. B. Saunders, Philadelphia 167-198.

PeACOCK, S. M., Jr. and Hodes, R. (1951). Influence of the forebrain on somatomotor activity. 11. Facilitation. J. Comp. Neurol. 94: 409-426.

Pollock, L. J. and Davis, L. (1930). The reflex activities of a decerebrate animal. J. Comp. Neurol. 50: $377-411$.

Pollock, L. J. and Davis, L. (1931). Studies in decerebration. VI. The effect of deafferentation upon decerebrate rigidity. Amer. J. Physiol. 98: 47-49.

Preston, J. B. (1956). Effects of chlorpromazine on the central nervous system of the cat: A possible neural basis for action. J. Pharmacol. 118: 100-115.

ShEATZ, G. C. (1955) Studies on chlorpromazine in decerebrate dogs and patients with irreversible brain damage. J. Pharmacol. 113: 47a.

Sherrington, C. S. (1898). Decerebrate rigidity and reflex coordination of movements. J. Physiol. 22: 319-332.

SiLVfSTRINI, B. and MAFFil, G. (1959). Effects of chlorpromazine, promazine, diethazine, reserpine, hydroxy zine and morphine upon some mono- and polysynaptic motor reflexes. J. Pharm. and Pharmacol. 11: $224-233$.

SNider, R. S., McCulloch, W. S. and Magoun, H. W. (1949). A cerebello-bulbo-reticular pathway for suppression. J. Neurophysiol. 12: 325-339.

Stella, G. (1944a). Sul meceanisimo della rigidita da decerebrazione in arti deafferentati. Atti soc. med. chir. Padova. 22: 5-16.

Stella, G. (1944b). Influenza del cerveletto sulla rigidita da decerebrazione. Atti soc. med. chir. Padova 22: $17-21$.

Su, C. and LeE, C. Y. (1960). The mode of neuromuscular blocking action of chlorpromazine. Brit. J. Pharmacol. 15: 88-94.

Terzuolo, C. (1954). Influences supraspinales sur le tetanes strychnique de la moelle epiniere. Arch int. Physiol. 62: 179-196.

VALDman, A. V. (1962). On the localization of the action of chlorpromazine and analgesics in reticular formation of the brain stem. Int. J. Neuropharmacol. 1: 197-200. 